Historic, Archive Document

Do not assume content reflects current scientific knowledge, policies, or practices. 



\title{
Ponderosa Pine Provenances for the Northern Great Plains
}

\author{
James L. Van Deusen
}

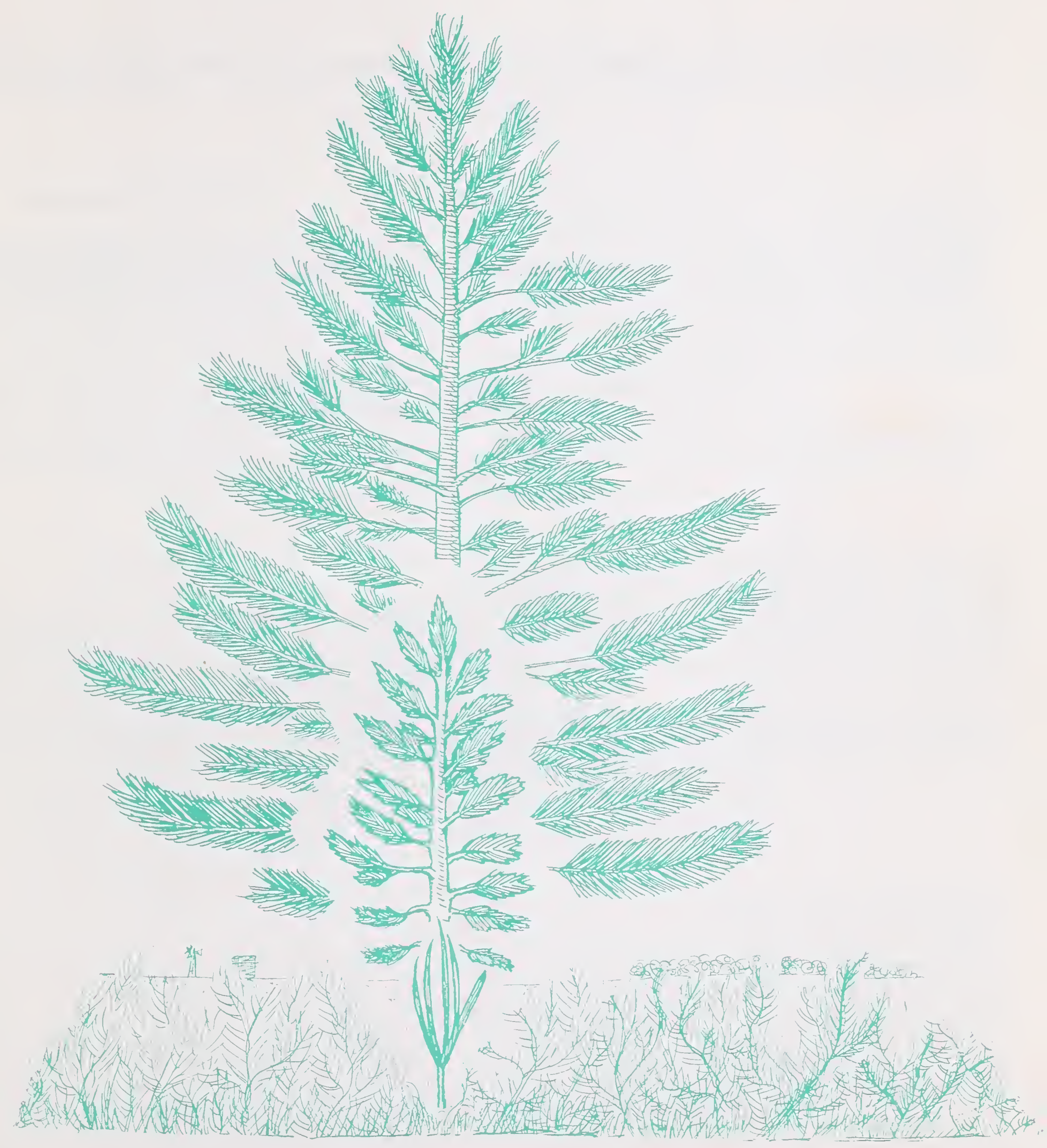

Research Paper RM-223

Rocky Mountain Forest and

Range Experiment Station

Forest Service

U.S. Department of Agriculture 


\title{
Ponderosa Pine Provenances for the Northern Great Plains
}

\author{
James L. Van Deusen, Research Forester \\ Rocky Mountain Forest and Range Experiment Station ${ }^{1}$
}

\begin{abstract}
Ponderosa pine trees representing 79 provenances were tested near Towner, N. Dak. Eight provenances can be recommended for planting in the northern Great Plains, based on 10 years in the plantation: 721 (Valentine, Nebr.); 720 (Ainsworth, Nebr.); 811 (Jordan, Mont.); (722 Chadron, Nebr.); 703 (Cave Hills, S. Dak.); 816 (York, Mont.); 704 (Slim Buttes, S. Dak.); and 757 (Rosebud, S. Dak.).
\end{abstract}




\title{
Ponderosa Pine Provenances for the Northern Great Plains
}

\author{
James L. Van Deusen
}

\section{Management Implications}

At least eight seed sources can be recommended for shelterbelt planting in the northern Great Plains. Nebraska sources 721, 720, and 722; South Dakota sources 703, 704, and 757; and Montana sources 811 and 816 have the combined height growth and survival capabilities needed for the northern Great Plains climate. They also were not damaged by sourcespecific attacks of insects, diseases, or animals. However, it is possible that, in the next 10 years, climatic extremes or other changes may cause slower growing sources to increase and presently fastgrowing sources to decrease; or, the relatively low levels of biotic stresses may increase so much that changes are necessary in the sources recommended.

Trees at the original collection sites are believed to be standing and producing satisfactory cone crops at the usual seed crop frequency for ponderosa pine of 2-to 3-year intervals. Specific directions to the recommended provenances are on file. ${ }^{2}$

${ }^{2}$ Rocky Mountain Forest and Range Experiment Station, Shelterbelt Laboratory, First and Brander, Bottineau, N. Dak.

\section{Introduction}

Ponderosa pine (Pinus ponderosa Laws.) is one of the few conifers known to be adapted to the northern Great Plains. It has the largest native geographic range of pines in North America and is a conifer widely used in shelterbelts throughout the Great Plains. However, even the widely distributed ponderosa is not native to large portions of the Great Plains, and must be tested to determine its suitability for a variety of sites.

Conifer windbreaks help lessen the drying, chilling, and aggravating effects of the persistent winds. In addition, erosive soils are less likely to be blown away, and snow is more uniformly distributed when prairie winds do not sweep, unmodified, across the fields.

Tree improvement research in the Great Plains is striving to identify species and seed sources of trees that will grow well under Plains conditions. Ponderosa pine can help satisfy that need, but best suited seed sources have not been identified for the variety of growing conditions encountered throughout the Plains.

A comprehensive study ${ }^{3}$ was designed to 1964 to: (1) find ponderosa pine seed sources best adapted for shelterbelt use in different regions of the Great Plains; (2) determine the range and distribution of genetic variation in the eastern range of ponderosa pine; and (3) provide plant material and data for progeny tests, seed orchard establishment, and breeding programs.

${ }^{3}$ Nienstaedt, Hans, and David H. Dawson. Study Work Plan: Ponderosa pine for the Great Plains Region. Document on file at Rocky Mountain Forest Range Experiment Station, Shelterbelt Laboratory, First and Brander, Bottineau, N. Dak.
Bulked seed samples from 79 sources (fig. 1 and table 1) were assembled by the Rocky Mountain Forest and Range Experiment Station's Bottineau, N. Dak., and Lincoln, Nebr. field units. Seeds came from 10 to 20 randomly selected trees growing at each collection site.

Plantations were established in 1968 and 1969 at 24 locations from Alberta and Saskatchewan, Canada. southward through the Plains to Oklahoma, and as far east as Pennsylvania.

\section{Study Area}

The North Dakota plantation was established in 1968, adjacent to the northern boundary of the State Forest Service Nursery at Towner, N. Dak., at an elevation of 1,480 feet ( $451 \mathrm{~m}$ ). Average annual precipitation is 16.8 inches ( $427 \mathrm{~mm}$ ), of which nearly $75 \%$ falls during the growing season. Average annual temperature is $39^{\circ} \mathrm{F}\left(4^{\circ} \mathrm{C}\right)$, but it can range from $100^{\circ} \mathrm{F}\left(38^{\circ} \mathrm{C}\right)$ to $-40^{\circ} \mathrm{F}\left(-40^{\circ} \mathrm{C}\right)$. The soil at the planting site is a Sioux loamy sand on level to gently undulating land, covered by native grasses and weeds.

\section{Methods and Materials}

Seedlings for this plantation were grown to $2+1$ age in the Towner Nursery. The plantation was established with 79 provenances, randomly arranged in each of 15 replications. Each replication consisted of 2 rows of 40 


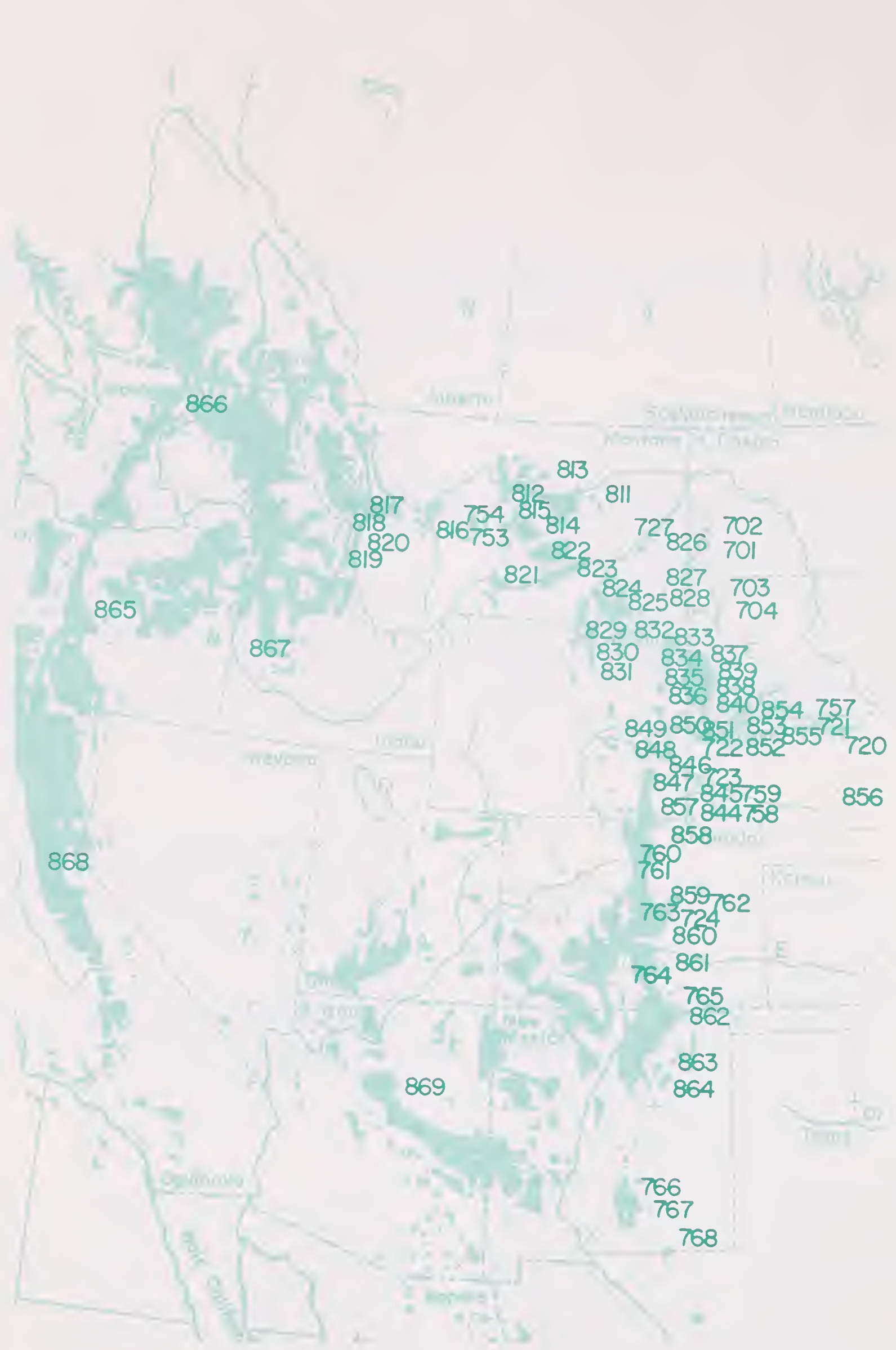

Figure 1.-Collection locations of ponderosa pine for the North Dakota provenance test (distribution map from Critchfield and Little 1966). 
Table 1.-Provenance location data for ponderosa pine provenance test at Towner, N. Dak.

\begin{tabular}{|c|c|c|c|c|c|c|c|}
\hline \multirow{2}{*}{$\begin{array}{c}\text { Geographical } \\
\text { clusters and } \\
\text { provenance } \\
\text { number }\end{array}$} & \multicolumn{3}{|c|}{ Source data } & \multirow{2}{*}{$\begin{array}{c}\text { Geographical } \\
\text { clusters and } \\
\text { provenance } \\
\text { number }\end{array}$} & \multicolumn{3}{|c|}{ Source data } \\
\hline & Latitude & Longitude & Elevation & & Latitude & Longitude & Elevation \\
\hline & ${ }^{\circ} \mathrm{N}$ & ${ }^{\circ} W$ & $m$ & & ${ }^{\circ} \mathrm{N}$ & ${ }^{\circ} W$ & $m$ \\
\hline $\begin{array}{l}\text { Oregon, Washington, } \\
\text { Idaho, and Montana }\end{array}$ & & & & $\begin{array}{l}\text { Low Elevation } \\
\text { Eastern Plains }\end{array}$ & & & \\
\hline Bitterroots & & & & 855 NE & 42.8 & 101.7 & 976 \\
\hline 865 OR & 44.0 & 121.3 & 1,311 & 757 SD & 43.3 & 101.0 & 793 \\
\hline 866 WA & 48.3 & 111.9 & 488 & 721 NE & 42.9 & 100.6 & 823 \\
\hline 867 ID & 44.0 & 116.0 & 1,037 & $720 \mathrm{NE}$ & 42.7 & 99.8 & 701 \\
\hline $817 \mathrm{MT}$ & 47.0 & 113.8 & 1,037 & $856 \mathrm{NE}$ & 41.5 & 100.1 & 884 \\
\hline $818 \mathrm{MT}$ & 46.7 & 114.2 & 1,433 & & & & \\
\hline $819 \mathrm{MT}$ & 45.9 & 114.2 & 1,250 & Central High Plains & & & \\
\hline $820 \mathrm{MT}$ & 46.2 & 114.0 & 1,372 & 759 NE & 41.5 & 103.1 & 1,310 \\
\hline & & & & $758 \mathrm{NE}$ & 41.3 & 103.3 & 1,372 \\
\hline Transition & & & & $858 \mathrm{CO}$ & 40.6 & 105.2 & 1,616 \\
\hline 816 MT & 46.7 & 111.8 & 1,372 & $859 \mathrm{CO}$ & 39.4 & 104.8 & 1,982 \\
\hline $754 \mathrm{MT}$ & 47.1 & 110.9 & 1,387 & $762 \mathrm{CO}$ & 39.4 & 103.8 & 1,799 \\
\hline $753 \mathrm{MT}$ & 47.0 & 110.3 & 1,220 & $724 \mathrm{CO}$ & 39.1 & 104.7 & 2,256 \\
\hline & & & & $860 \mathrm{CO}$ & 38.6 & 105.0 & 1,982 \\
\hline Central Montana & & & & $861 \mathrm{CO}$ & 38.0 & 105.0 & 2,012 \\
\hline $815 \mathrm{MT}$ & 47.0 & 109.3 & 1,463 & & & & \\
\hline $814 \mathrm{MT}$ & 47.0 & 109.0 & 1,128 & Black Hills and & & & \\
\hline $813 \mathrm{MT}$ & 47.9 & 108.6 & 1,433 & Northern Plains & & & \\
\hline $812 \mathrm{MT}$ & 47.5 & 109.5 & 1,037 & $811 \mathrm{MT}$ & 47.6 & 107.0 & 884 \\
\hline $821 \mathrm{MT}$ & 45.8 & 109.0 & 1,159 & $822 \mathrm{MT}$ & 46.3 & 108.5 & 1,159 \\
\hline $823 \mathrm{MT}$ & 46.1 & 107.4 & 884 & $727 \mathrm{MT}$ & 46.9 & 105.2 & 808 \\
\hline 829 WY & 44.8 & 107.4 & 1,555 & $826 \mathrm{MT}$ & 47.0 & 104.7 & 838 \\
\hline & & & & 702 ND & 47.0 & 103.5 & 762 \\
\hline Central Rockies & & & & 701 ND & 46.6 & 103.5 & 793 \\
\hline 830 WY & 44.7 & 107.1 & 2,134 & $824 \mathrm{MT}$ & 46.0 & 106.6 & 1,037 \\
\hline 831 WY & 44.2 & 106.9 & 1,768 & $825 \mathrm{MT}$ & 45.7 & 106.0 & 1,098 \\
\hline 849 WY & 42.8 & 105.1 & 1,585 & $827 \mathrm{MT}$ & 45.9 & 104.5 & 1,159 \\
\hline $848 W Y$ & 42.6 & 105.7 & 2,104 & $828 \mathrm{MT}$ & 45.6 & 104.2 & 1,220 \\
\hline 847 WY & 42.3 & 105.3 & 1,677 & 703 SD & 45.9 & 103.5 & 976 \\
\hline 857 WY & 41.2 & 105.3 & 2,348 & 704 SD & 45.6 & 103.2 & 1,052 \\
\hline 845 NE & 41.5 & 104.0 & 1,555 & $832 W Y$ & 45.0 & 105.6 & 1,189 \\
\hline 844 NE & 41.2 & 104.1 & 1,585 & $833 \mathrm{WY}$ & 44.7 & 104.3 & 1,220 \\
\hline $760 \mathrm{CO}$ & 40.2 & 105.6 & 2,561 & 834 WY & 44.5 & 104.5 & 1,677 \\
\hline $761 \mathrm{CO}$ & 40.0 & 105.5 & 2,439 & $835 W Y$ & 43.9 & 104.2 & 1,549 \\
\hline $763 \mathrm{CO}$ & 39.1 & 105.1 & 2,378 & 836 WY & 43.7 & 104.1 & 1,244 \\
\hline $764 \mathrm{CO}$ & 38.0 & 105.3 & 2,683 & 837 SD & 44.3 & 103.9 & 1,921 \\
\hline & & & & 838 SD & 44.0 & 103.7 & 1,732 \\
\hline Southern Rockies & & & & 839 SD & 44.2 & 103.6 & 1,646 \\
\hline and Plains & & & & 840 SD & 43.8 & 103.4 & 1,280 \\
\hline $765 \mathrm{CO}$ & 37.4 & 104.8 & 2,134 & $850 W Y$ & 42.9 & 104.5 & 1,524 \\
\hline 862 NM & 37.0 & 104.3 & 2,241 & 851 NE & 42.7 & 103.6 & 1,280 \\
\hline 863 NM & 35.9 & 105.0 & 1,951 & 846 WY & 42.2 & 104.5 & 1,280 \\
\hline 864 NM & 35.5 & 105.3 & 1,951 & 723 NE & 41.8 & 103.9 & 1,402 \\
\hline 766 NM & 33.3 & 105.6 & 2,226 & 722 NE & 42.7 & 103.1 & 1,311 \\
\hline $767 \mathrm{NM}$ & 33.0 & 105.4 & 1,951 & 852 NE & 42.6 & 102.5 & 1,159 \\
\hline $768 \mathrm{NM}$ & 32.2 & 104.8 & 1,768 & 853 NE & 43.0 & 102.5 & 1,098 \\
\hline $869 \mathrm{AZ}$ & 35.2 & 111.8 & 2,134 & 854 SD & 43.3 & 101.8 & 1,006 \\
\hline
\end{tabular}

provenances each, or a total of 30 rows. Each plot had four trees from one provenance, planted in a line. Trees which died in the first year were replaced in spring 1969 from appropriate transplanted stock.

Rows 2 feet $(61 \mathrm{~cm})$ wide were tilled 12 feet $(3.7 \mathrm{~m})$ apart, and were oriented generally north-south. The 2 -foot $(61-\mathrm{cm})$ width adequately prepared the planting site, but native vegetation was not tilled between rows to retain control of the erosive soil. Trees were machine-planted in May, spaced 8 feet $(2.5 \mathrm{~m})$ apart within rows.
Because grass and weed competition is detrimental to tree survival and growth in the Great Plains, competing vegetation was annually cultivated or sprayed with herbicides in bands adjacent to tree rows during the 10 -year period. Weeds between tree rows were mowed annually. Simazine at 2 pounds (907 g) a.i. per acre was applied, generally in mixture with dalapon at 10 pounds ( $4.53 \mathrm{~kg}$ ) a.i. per acre. To add nutrients to the sandy soil, a granular 23-23-0 fertilizer was scattered in a $3-$ foot $(1-m)$ circle around each live tree in three of the last four years. 


\section{Results and Discussion}

\section{Survival}

After the first three field seasons, survival was good, except for the southernmost provenances. But among those, even the New Mexican provenances were surviving at a rate of one tree out of three. Southern Rockies and Plains trees were killed probably by low winter temperatures rather than competition for soil moisture.

Survival by age 10 reflected the combined effects of low temperatures and soil moisture stresses. Source 703 from northwestern South Dakota had $85 \%$ survival, which was twice the plantation average. Ten provenances, however, had less than 10\% survival after 10 years. Tenth-year survival for all sources ranged from $0 \%$ to $85 \%$ (table 2).

Although low winter temperatures may have been responsible for early mortality, competition for soil moisture was probably the most critical factor in survival. Despite the tilling, spraying, and mowing, some portions of the rooting zone of plantation trees prob- ably had strong competition from weeds and grasses for soil moisture at all times. Because the soil at the plantation site has a poor moisture-holding capacity, survival and growth heavily depend on current precipitation. Four of the last five years had below-normal precipitation during the growing season, April through August. In 1976, precipitation for that period was 3.91 inches $(9.9 \mathrm{~cm})$ below normal; in 1977, it was 1.3 inches $(3.3 \mathrm{~cm})$ below normal.

\section{Height}

Tallest provenance was $721 \mathrm{NE}$ (fig. 2a) which averaged 41 inches $(104 \mathrm{~cm}), 50 \%$ taller than the plantation average (table 2). Height growth of all trees was not as good as expected; the plantation average of only 28 inches $(70 \mathrm{~cm})$ is equivalent to less than 3 inches $(7$ $\mathrm{cm}$ ) per year (fig. 2b). Trees from the best provenance grew nearly 4 inches $(10 \mathrm{~cm})$ per year. Ponderosa pines at the nearby Denbigh Experimental Forest, on similar soils and from some of the same areas, have grown approximately 1 foot $(30 \mathrm{~cm})$ per year, for the past 40 years. Limited soil moisture, caused by grass and weed
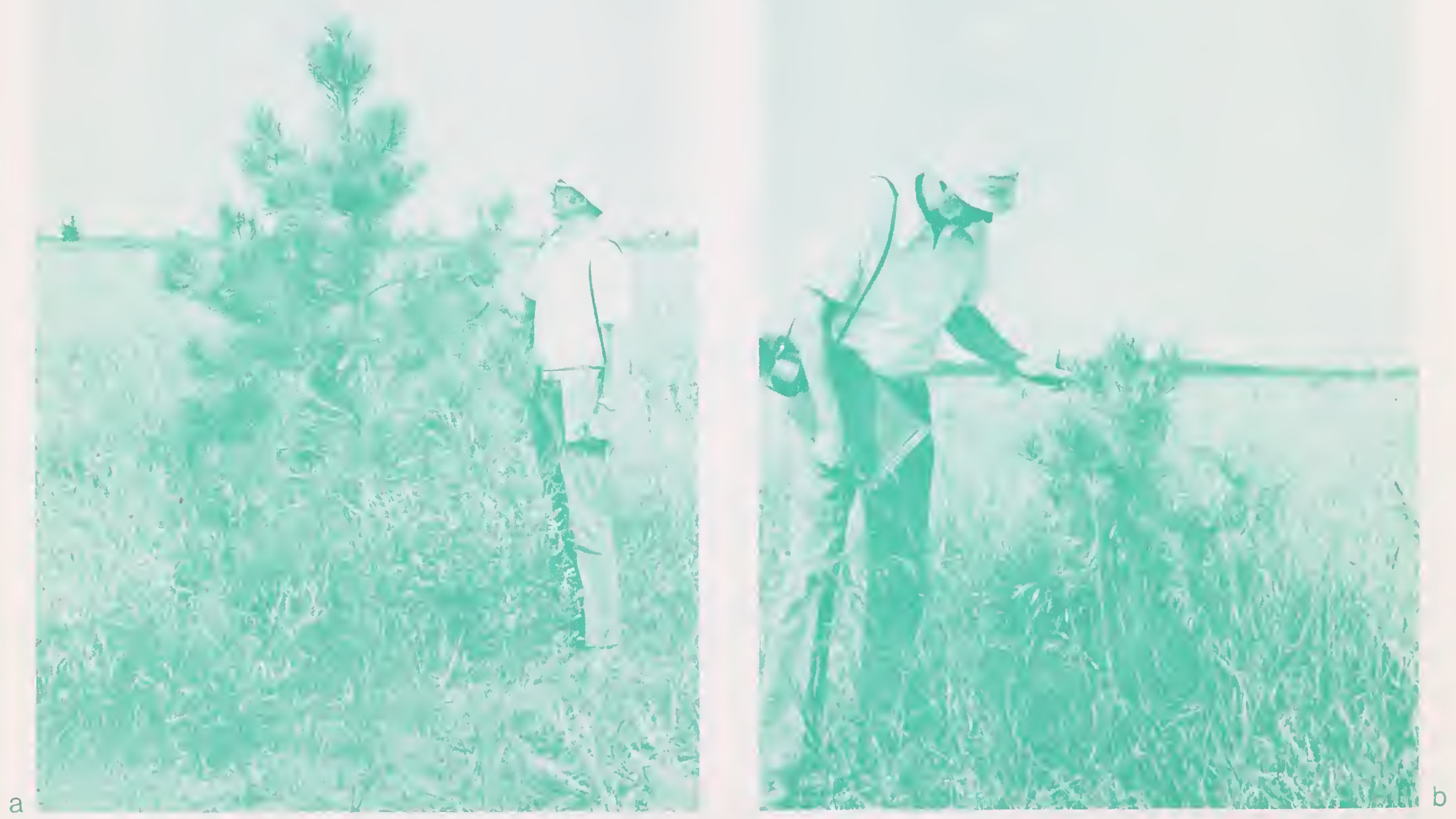

Figure 2.-Two ponderosa pine trees after 10 growing seasons in the field. Tree in (a) is from the best provenance ( $721 \mathrm{NE})$, while the tree in (b) is from a North Dakota provenance (702), growing at approximately the average plantation rate. 
Table 2.-North Dakota ponderosa pine provenance test; average survival and height growth for 79 provenances

\begin{tabular}{|c|c|c|c|c|c|}
\hline $\begin{array}{c}\text { Geographical } \\
\text { clusters and } \\
\text { provenance } \\
\text { number }\end{array}$ & $\begin{array}{l}\text { Survival } \\
10 \text {-year }\end{array}$ & $\begin{array}{c}\text { Tree } \\
\text { height } \\
10 \text {-year }\end{array}$ & $\begin{array}{c}\text { Geographical } \\
\text { clusters and } \\
\text { provenance } \\
\text { number }\end{array}$ & $\begin{array}{l}\text { Survival } \\
10 \text {-year }\end{array}$ & $\begin{array}{l}\text { Tree } \\
\text { height } \\
\text { 10-year }\end{array}$ \\
\hline & $\%$ & $\mathrm{~cm}$ & & $\%$ & $\mathrm{~cm}$ \\
\hline $\begin{array}{l}\text { Oregon, Washington, } \\
\text { Idaho, and Montana }\end{array}$ & & & $\begin{array}{l}\text { Low Elevation } \\
\text { Eastern Plains }\end{array}$ & & \\
\hline Bitterroots & & & $855 \mathrm{NE}$ & 53 & 74 \\
\hline 865 OR & 18 & 38 & 757 SD & 62 & 98 \\
\hline 866 WA & 10 & 44 & $721 \mathrm{NE}$ & 82 & 104 \\
\hline 867 ID & 2 & 75 & $720 \mathrm{NE}$ & 72 & 98 \\
\hline $817 \mathrm{MT}$ & 10 & 77 & $856 \mathrm{NE}$ & 58 & 75 \\
\hline $\begin{array}{l}819 \mathrm{MT} \\
820 \mathrm{MT}\end{array}$ & 15 & $\begin{array}{l}48 \\
53\end{array}$ & $\begin{array}{l}\text { Central } \\
\text { High Plains }\end{array}$ & & \\
\hline & & & $760 \mathrm{NE}$ & 55 & 60 \\
\hline $\begin{array}{c}\text { Transition } \\
\text { 816 MT }\end{array}$ & & & $758 \mathrm{NE}$ & 42 & 64 \\
\hline $\begin{array}{l}816 \mathrm{MT} \\
754 \mathrm{MT}\end{array}$ & 72 & 86 & $858 \mathrm{CO}$ & 38 & 51 \\
\hline $\begin{array}{l}754 \mathrm{MT} \\
753 \mathrm{MT}\end{array}$ & 77 & 81 & $859 \mathrm{CO}$ & 23 & 41 \\
\hline $753 \mathrm{MT}$ & 75 & 66 & $\begin{array}{l}762 \mathrm{CO} \\
724 \mathrm{CO}\end{array}$ & $\begin{array}{l}63 \\
38\end{array}$ & $\begin{array}{l}58 \\
55\end{array}$ \\
\hline Central Montana & & & $860 \mathrm{CO}$ & $\begin{array}{l}38 \\
18\end{array}$ & $\begin{array}{l}55 \\
34\end{array}$ \\
\hline $815 \mathrm{MT}$ & 67 & 78 & $861 \mathrm{CO}$ & 8 & 45 \\
\hline $814 \mathrm{MT}$ & 63 & 77 & & & \\
\hline $813 \mathrm{MT}$ & 63 & 72 & Black Hills and & & \\
\hline $812 \mathrm{MT}$ & 55 & 72 & Northern Plains & & \\
\hline $821 \mathrm{MT}$ & 68 & 74 & $811 \mathrm{MT}$ & 82 & 90 \\
\hline $823 \mathrm{MT}$ & 58 & 80 & $822 \mathrm{MT}$ & 70 & 74 \\
\hline $829 W Y$ & 43 & 63 & $727 \mathrm{MT}$ & 70 & 86 \\
\hline & & & $826 \mathrm{MT}$ & 70 & 68 \\
\hline Central Rockies & & & 702 NE & 57 & 68 \\
\hline 830 WY & 47 & 65 & 701 ND & 50 & 63 \\
\hline 831 WY & 45 & 55 & $824 \mathrm{MT}$ & 60 & 80 \\
\hline 849 WY & 57 & 53 & $\begin{array}{l}825 \mathrm{MT} \\
827 \mathrm{MT}\end{array}$ & 58 & 87 \\
\hline 848 WY & 52 & 44 & $\begin{array}{l}827 \mathrm{MT} \\
828 \mathrm{MT}\end{array}$ & 57 & 72 \\
\hline 847 WY & 12 & 69 & $\begin{array}{l}828 \mathrm{MT} \\
703 \mathrm{SD}\end{array}$ & $\begin{array}{l}52 \\
85\end{array}$ & 73 \\
\hline 857 WY & 23 & 38 & $\begin{array}{l}703 \text { SD } \\
704 \text { SD }\end{array}$ & $\begin{array}{l}85 \\
73\end{array}$ & 79 \\
\hline 845 NE & 38 & 57 & 832 WY & $\begin{array}{l}73 \\
43\end{array}$ & 72 \\
\hline 844 NE & 37 & 50 & $833 W Y$ & $\begin{array}{l}43 \\
42\end{array}$ & 58 \\
\hline $760 \mathrm{CO}$ & 43 & 51 & $834 W Y$ & $\begin{array}{l}42 \\
45\end{array}$ & 68 \\
\hline $761 \mathrm{CO}$ & 75 & 66 & 835 WY & $\begin{array}{l}45 \\
52\end{array}$ & $\begin{array}{l}74 \\
61\end{array}$ \\
\hline $\begin{array}{l}763 \mathrm{CO} \\
764 \mathrm{CO}\end{array}$ & $\begin{array}{l}70 \\
50\end{array}$ & $\begin{array}{l}79 \\
50\end{array}$ & 836 WY & 58 & 65 \\
\hline $104 \cup 0$ & & 50 & $\begin{array}{l}837 \text { SD } \\
838 \mathrm{SD}\end{array}$ & 55 & 70 \\
\hline Southern Rockies & & & 839 SD & 60 & 60 \\
\hline and Plains & & & 840 SD & 42 & 59 \\
\hline $765 \mathrm{CO}$ & 15 & 35 & 850 WY & 55 & 58 \\
\hline 862 NM & 2 & 15 & $851 \mathrm{NE}$ & 50 & 57 \\
\hline 863 NM & 2 & 8 & 846 WY & 38 & 46 \\
\hline $864 \mathrm{NM}$ & 0 & 0 & $723 \mathrm{NE}$ & 68 & 75 \\
\hline 766 NM & 0 & 0 & 722 NE & 73 & 82 \\
\hline 767 NM & 0 & 0 & 852 NE & 45 & 65 \\
\hline \multirow{3}{*}{$\begin{array}{l}768 \mathrm{NM} \\
869 \mathrm{AZ}\end{array}$} & 0 & 0 & 853 NE & 52 & 72 \\
\hline & 0 & 0 & 854 SD & 43 & 59 \\
\hline & & & Means & ${ }^{1} 42.4$ & ${ }^{2} 69.5$ \\
\hline
\end{tabular}

'Survival percent transformed into arcsin $\sqrt{\%}$ for each provenance, then averaged for the plantation and converted back to percent.

${ }^{2}$ Weighted by number of surviving trees in each provenance. 
competition, probably reduced height growth for all provenances. Trees from the only two North Dakota provenances in the plantation $(701,702)$ grew at slightly less than the plantation average (table 2).

When height growth data at plantation ages 3, 5, and 10 were grouped into geographical clusters, ${ }^{4}$ the clusters maintained their relative positions throughout the 10-year period (fig. 3). Height growth of provenances from the southern Rockies and Great Plains is distinctly inferior to other clusters.

Several of the tallest provenances at Towner also are among the tallest provenances at other planting sites (table 3). For example, provenances $721 \mathrm{NE}$, $720 \mathrm{NE}, 757 \mathrm{SD}, 811 \mathrm{MT}$, and $825 \mathrm{MT}$ have been among the best growers in three to six other widely scattered plantations. It also offers encouragement that while trees at Towner generally are shorter than at other plantations, most of the best provenances at Towner have also been among the leaders elsewhere.

\section{Geographical Clusters}

When the provenances were grouped into geographical clusters, there were statistically significant differ-

"Read, Ralph A. Genetic variation in seedling progeny of ponderosa pine provenances. Manuscript submitted to Forest Science Monograph in 1979. ences in mean survival and height growth among clusters (table 4). No multiple range tests were made. Table 2 shows that most clusters have substantial performance variations among the included provenances.

\section{Early Performance Indicators}

If trees that will continue to be outstanding growers can be recognized from juvenile growth, substantial time can be saved in tree improvement. There was an excellent correlation between average tree height at plantation ages 5 and 10 for the 10 tallest provenances.

Table 3.-Number of provenances, from lists of the 10 tallest provenances at comparison plantations, ${ }^{1}$ which were also among the 10 tallest at Towner, N. Dak.

\begin{tabular}{lcc}
\hline $\begin{array}{c}\text { Plantation } \\
\text { location }\end{array}$ & $\begin{array}{c}\text { Number of } \\
\text { sources }\end{array}$ & $\begin{array}{c}\text { Years of } \\
\text { record }\end{array}$ \\
\hline Phillipsburg, Pa. & 4 & 9 \\
Watertown, S. Dak. & 5 & 10 \\
Alliance, Nebr. & 4 & 10 \\
Hastings, Nebr. & 5 & 10 \\
Junction City, Kans. & 5 & 10 \\
Norman, Okla. & 5 & 10 \\
\hline
\end{tabular}

'First decade data in process of analysis by Ralph A. Read.

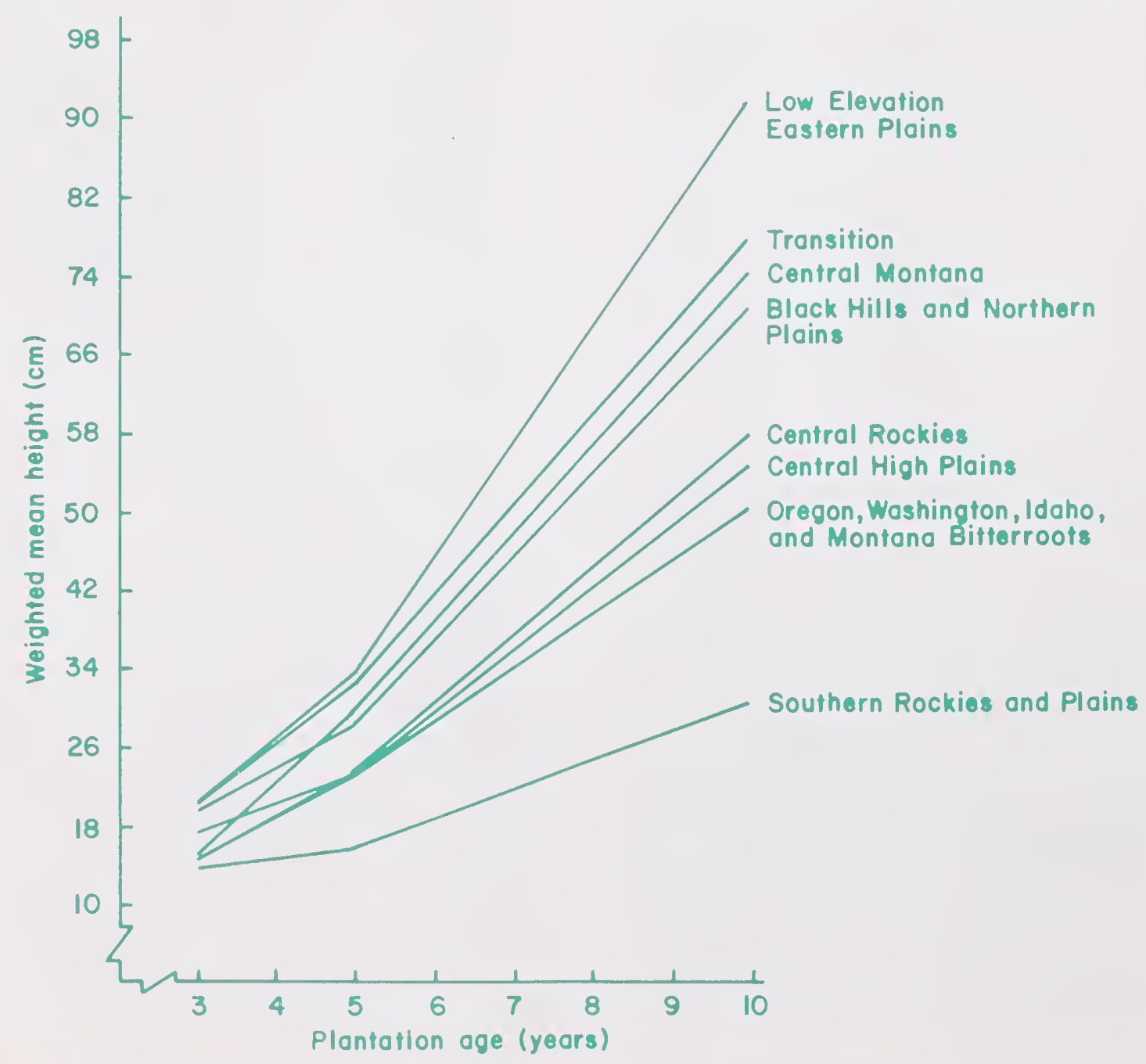

Figure 3.-Weighted mean height growth of eight geographical clusters of ponderosa pines at Towner, N. Dak. 
Table 4.- Ten-year mean survival and height growth of eight cluster groups of ponderosa pine' provenances at Towner, N. Dak.

\begin{tabular}{lcc}
\hline & \multicolumn{2}{c}{ Means $^{2}$} \\
\cline { 2 - 3 } Geographical cluster & Survival ${ }^{3}$ & Height $^{4}$ \\
\hline & 74 & $\mathrm{~cm}$ \\
Transition & 66 & 78 \\
Low Elevation Eastern Plains & 60 & 91 \\
Central Montana & 58 & 71 \\
Black Hills and Northern Plains & 45 & 58 \\
Central Rockies & 35 & 54 \\
Central High Plains & 11 & 51 \\
Oregon, Washington, Idaho, and & 5 & 30 \\
Montana Bitterroots & & \\
Southern Rockies and Plains & 42 & 70 \\
Plantation total and averages
\end{tabular}

'The variety scopulorum is represented in all clusters except Oregon, Washington, Idaho, and Montana Bitterroots which is var. ponderosa, and Transition which is a transition between var. scopulorum and var. ponderosa.

${ }^{2}$ Analysis of variance indicated means differed significantly at the $1 \%$ level.

${ }^{3}$ Transformed into arcsin $\sqrt{\%}$ for provenances and converted back to percent for cluster averages.

"Weighted averages.

The 10 tallest provenances, listed in order of decreasing mean height, are:

$\begin{array}{cc}\text { Age 5 } & \text { Age 10 } \\ 721 & 721 \\ 811 & 757 \\ 757 & 720 \\ 720 & 811 \\ 825 & 825 \\ 722 & 816 \\ 816 & 727 \\ 727 & 722 \\ 824 & 754 \\ 754 & 824\end{array}$

None of the changes at age 10 involve a shift of more than two positions. Relative ranking of all 79 provenances could not be predicted so well between ages 5 and 10 , but the leaders seemed to maintain their superiority. The list of 10 tallest provenances does not include all the recommended provenances for seed collections because recommendations for seed collections take survival into account as well as height growth. Some of the provenances with good survival grew almost as fast as the 10 tallest.

\section{Combining Traits}

A single trait such as 10-year height growth or 10-year survival does not fully indicate performance. A very few tall trees, or survival of many short ones, is not enough to recommend those provenances as seed collection areas. Fortunately, the best growing sources generally were also the ones with best survival and were not affected seriously by insects, diseases, or animals.

To decide which provenances to recommend for northern Great Plains plantings, a scheme suggested by Read ${ }^{5}$ was used to combine the survival and height growth of provenances into a rank order. Four groups of six equal index classes (0-5) for survival and tree height were set up based on survival and height expressed as a percentage of the plantation mean. The average survival and height growth of each provenance, which had been calculated as a percentage of the plantation mean, was assigned to its appropriate index class. Then, the two indexes were summed for each provenance to make a total rating which combined relative survival and height growth.

For example, the range in percentages of the plantation mean for survival was $0 \%$ to $203 \%$. Any provenance with a survival rate of $0 \%$ to $33 \%$ of the plantation mean was assigned an index of 0 , while at the other extreme, those with a survival rate of $170 \%$ to $203 \%$ of the plantation mean, received an index rating of 5. Provenances $721 \mathrm{NE}, 720 \mathrm{NE}$, and $811 \mathrm{MT}$ rated 5 in each category, with a combined rating of 10 each.

To be recommended for northern Great Plains plantings, provenances must have a total rating of 9 . Of all provenances rated, only eight were rated at 9 or 10: 721 (Valentine, Nebr.); 720 (Ainsworth, Nebr.); 811 (Jordan, Mont.); 722 (Chadron, Nebr.); 703 (Cave Hills, S. Dak.); 816 (York, Mont.); 704 (Slim Buttes, S. Dak.); and 757 (Rosebud, S. Dak.).

Mean survival and height growth of the eight leading sources was substantially better than plantation means. Mean survival for the leading sources was $73.9 \%$, compared to the plantation mean of $42.4 \%$. Mean height for the leading provenances was $90.1 \mathrm{~cm}$; much higher than the plantation mean of $69.5 \mathrm{~cm}$.

\section{Winter Injury}

Native and planted pines throughout the northern Great Plains suffered varying amounts of winter injury during the winter of 1978-79. Ponderosa pines probably were damaged more than other species. At Towner, N. Dak., injury to plantation trees ranged from insignificant browning of some needle tips to tree mortality.

During spring 1979, before winter injury symptoms had been obliterated by new growth, all live trees in the plantation were surveyed for winter damage. ${ }^{6}$ The leading survivors and best growers were from provenances whose trees were least affected by winter injury. Provenance $721 \mathrm{NE}$ had 26 trees with few or no injury symptoms. The next four most resistant provenances had only $40 \%$ as many injury-free trees: 727 MT and 811 MT (11 trees); $753 \mathrm{MT}$ and $829 \mathrm{WY}$ (10 trees).

${ }^{3}$ Personal communication from Ralph A. Read. October 22, 1979.

- Personal communication from Richard Gilmore. North Dakota Forest Service. 


\section{Biotic Stresses}

No serious insect, disease, or animal damage has developed in the plantation. Damage from the western pine tip moth (Rhyacionia bushnelli Busck) has been of little consequence. The limited infestations that have been noted have been concentrated on the southern portions of the plantation, near existing rows of polesize ponderosa pines that shelter the Towner Nursery. No provenance-related trends of infestation have appeared.

Common diseases such as the western gall rust (Peridermium harknessii J. P. Moore) are extremely rare in the plantation, even though gall rust is found in the vicinity.
Deer, porcupines, mice, or rabbits have made a minimum impact on plantation trees. Read (1971), however, reported preferences by jackrabbits for certain provenances in Nebraska.

\section{Literature Cited}

Critchfield, W. B., and E. L. Little, Jr. 1966. Geographic distribution of the pines of the world. U.S. Department of Agriculture, Miscellaneous Publication 991, 97 p. Washington, D.C.

Read, Ralph A. 1971. Browsing preference by jackrabbits in a ponderosa pine provenance plantation. USDA Forest Service Research Note RM-186, 4 p. Rocky Mountain Forest and Range Experiment Station, Fort Collins, Colo.

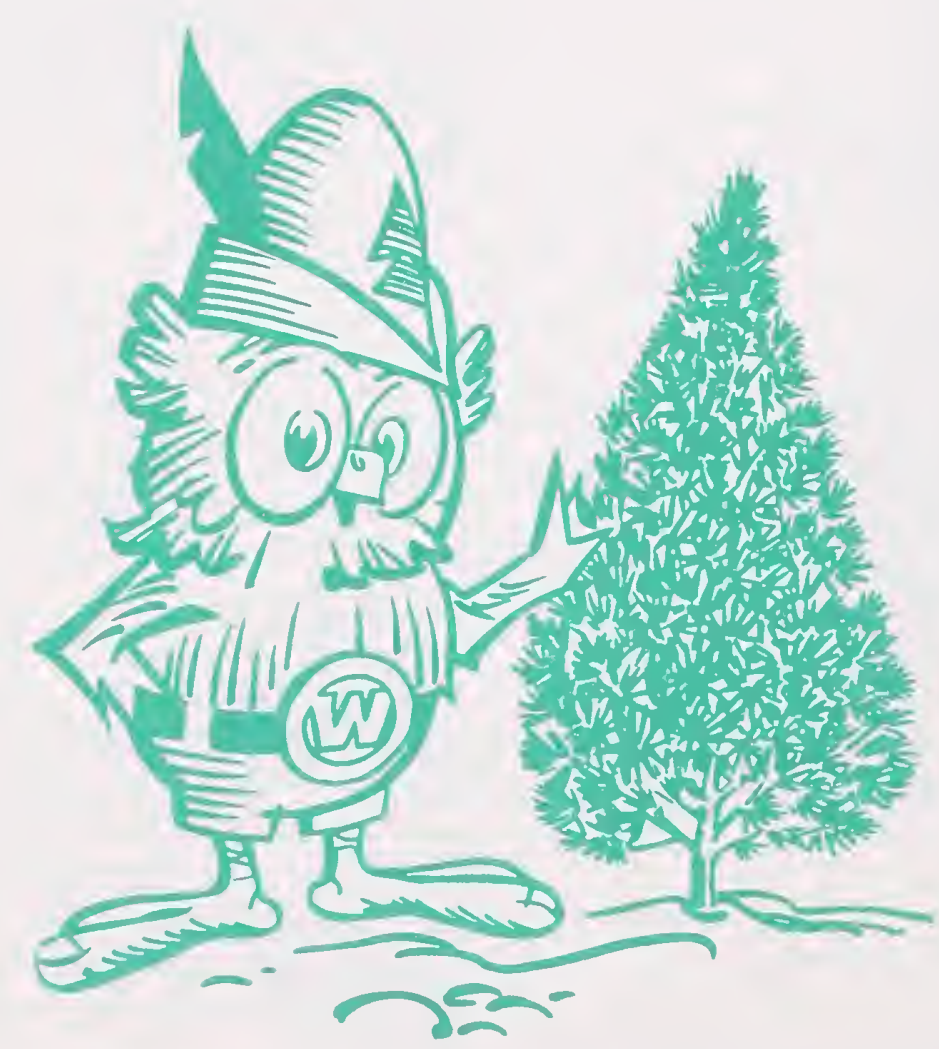

Plant a tree! Mark the 75th birthday of the Forest Service by giving a living gift to future generations. 

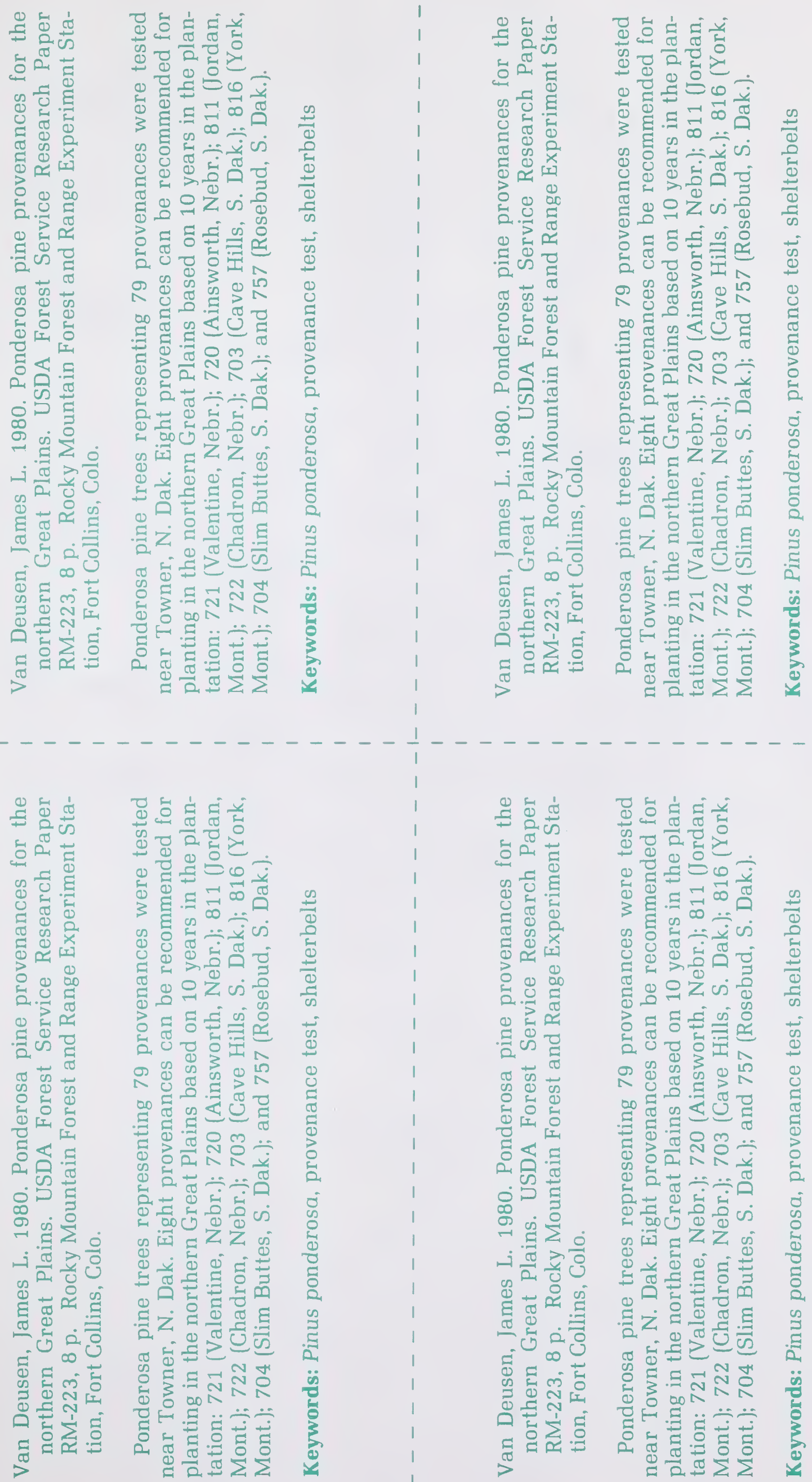


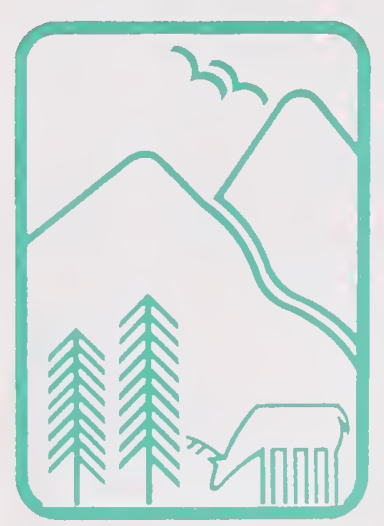

Rocky
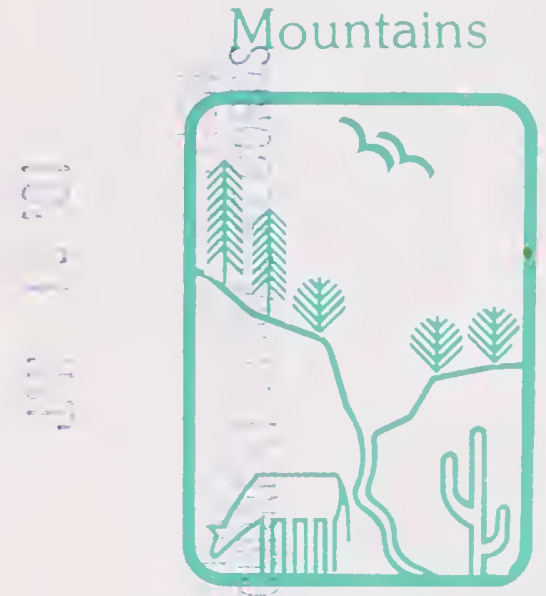

Southwest

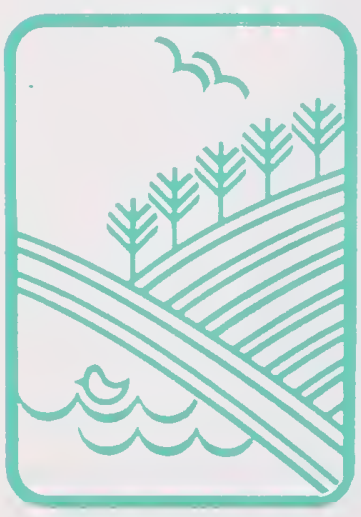

Great

Plains
U.S. Department of Agriculture Forest Service

\section{Rocky Mountain Forest and Range Experiment Station}

The Rocky Mountain Station is one of eight regional experiment stations, plus the Forest Products Laboratory and the Washington Office Staff, that make up the Forest Service research organization

\section{RESEARCH FOCUS}

Research programs at the Rocky Mountain Station are coordinated with area universities and with other institutions. Many studies are conducted on a cooperative basis to accelerate solutions to problems involving range, water, wildlife and fish habitat, human and community development, timber, recreation, protection, and multiresource evaluation.

\section{RESEARCH LOCATIONS}

Research Work Units of the Rocky Mountain Station are operated in cooperation with universities in the following cities:

Albuquerque, New Mexico

Bottineau, North Dakota

Flagstaff, Arizona

Fort Collins, Colorado*

Laramie, Wyoming

Lincoln, Nebraska

Lubbock, Texas

Rapid City, South Dakota

Tempe, Arizona

- Station Headquarters: 240 W. Prospect St., Fort Collins, CO 80526 